\title{
NEW SURVEY OF LEAD AND ZINC ORE MINERALIZATION IN REPUBLIC OF KOSOVO
}

\author{
Joanna KOLODZIEJCZYK ${ }^{1}$, Jaroslav PRŠEK ${ }^{1}$, \\ Halil QELA² \& Burim ASLLANI ${ }^{2}$ \\ ${ }^{1}$ AGH University of Science and Technology, Faculty of Geology, Geophysics \\ and Environmental Protection; \\ al. A. Mickiewicza 30,30-059 Krakow,Poland; e-mail: asia.office@wp.pl \\ ${ }^{2}$ Trepça Mines, Prishtine, 10000, Republic of Kosovo
}

\begin{abstract}
Kosovo lead and zinc ore deposits are located in the Trepça Belt which extends for over $80 \mathrm{~km}$. Several ore deposits occur in that belt, with the most important - Stan Terg (Trepça). Stan Terg deposit originating at the contact between volcanic breccias and carbonate rocks. Two different types of mineralization can be distinguished. The older one has origin related to pneumatolitic processes, when skarns were formed. The more recent one was formed by hydrothermal processes and has the largest economic importance. Over 70 minerals have been recognized in the Trepça deposit. Further mineralogical investigations will allow for the identification of other rare minerals.
\end{abstract}

Key words: ore mineralogy, Kosovo, Trepça deposit

\section{INTRODUCTION}

The beginnings of silver and gold mining activities in Kosovo go back to the pre-Roman times. The former gold and silver mining is connected with a $\mathrm{Pb}+\mathrm{Zn}$ ore deposit. The modern history of mining started in 1930, when Trepça Mines Ltd. opened the first mine in Stan Terg. Production was continued until 1999, when the infrastructure was almost damaged due to a political conflict (Hyseni et al. 2010). Currently, the company operates under the name Trepça - Enterprise under PAK Administration. There are four active $\mathrm{Pb}+\mathrm{Zn}$ mines in Kosovo: Stan Terg, Artana (Novo Brdo), Belo Brdo and Crnac. More mines will be open or re-open in the near future: Hajvalija, Përroi i Thartë and Badoc.

Researchers and students of the Faculty of Geology, Geophysics and Environmental Protection at the AGH University of Science and Technology in Cracow organized three excursions during the year of 2011 to Kosovo. As a result, cooperation with Trepça management has been established and a new joint survey of the various sites began. 
I - Batiava - Artana Zone

II - Belo Brdo - Stan Terg - Hajvalia Zone

III - Crnac Zone

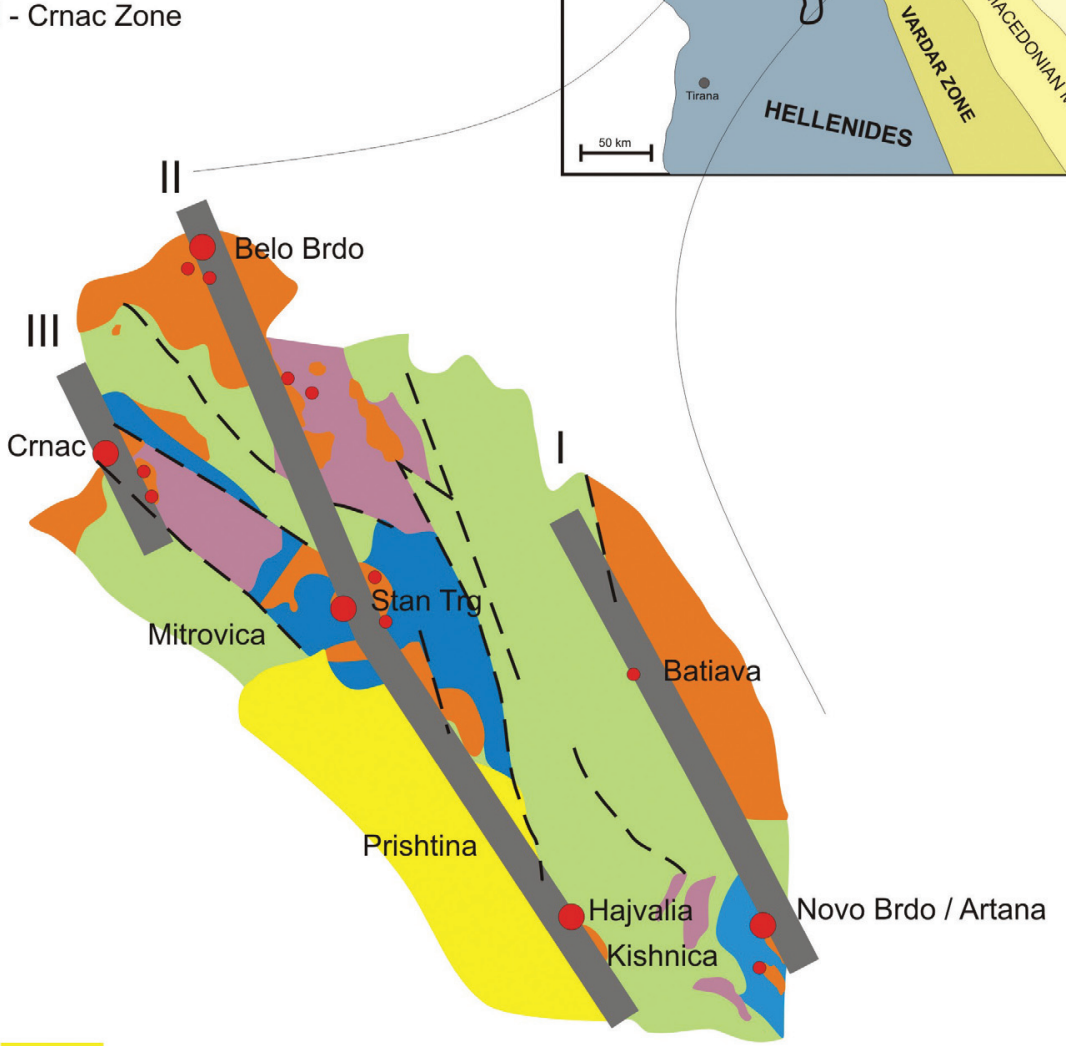

Miocene sediments

Tetriary volcanics \& volcaniclastics

Jurassic \& Cretaceous sediments

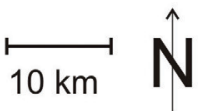

Serpentinised peridotite

- Mine

- Mineralization occurrences

Triassic and Paleozic metasediments

Fig. 1. Geotectonic setting of Vardar Zone and Trepça Mineral Belt units (Hyseni et al. 2010, modified) 


\section{GEOLOGICAL SETTING}

Lead and zinc mineralization in the Trepça Belt is closely related to the NNW-SSE trending Vardar Zone, which marks the fundamental junction between the Serbo-Macedonian Massif to the east and the Dinarides to the west (Fig. 1) (Hyseni et al. 2010). This structure is characterized by Paleozoic crystalline schists and phyllites overlain by Triassic clastics, phyllites and volcanoclastic rocks, Upper Triassic carbonates, Jurassic serpentinized ultrabasic rocks, gabbros, diabases and sediments of the ophiolite association, Cretaceous complex series of mélange and the Tertiary (Oligocene-Miocene) andesite, trachyte and latite sub-volcanic intrusives, volcanics and pyroclastic rocks (Miletic, 1997 in Hyseni et al. 2010).

Within the Vardar Zone, the Trepça Belt can be distinguished. The Belt is one of the largest $\mathrm{Pb}+\mathrm{Zn}$ ore areas in Europe and extends for over $80 \mathrm{~km}$ in northern Kosovo and includes numerous lead and zinc deposits and occurrences. Three regional (NNW-SSE) trending zones of mineralization within the Belt are recognized (Fig. 1). Zone I includes Artana deposits and follows the boundary marked by extensive Neogene calc-alkaline volcanics and intrusive rocks. Zone II contains Hajvalija, Badoc, Belo Brdo and Stan Terg deposits and follows the major fault on the eastern margin of the Miocene Prishtina basin and the intrusive and volcanic complexes in northern Kosovo, whereas Zone III with Crnac deposit occurs on the western border of the Vardar Zone at its contact with Dinarides (Hyseni et al. 2010).

\section{THE TREPÇA MINERAL BELT}

The Trepça Mineral Belt (the Kopaonik metallogenic district) contains different types of $\mathrm{Pb}+\mathrm{Zn}+\mathrm{Ag}$ mineralization such as skarn, hydrothermal replacement and vein type of deposits (Jankovic 1995). Ores are of various types: sulphide, sulphosalt and carbonate ones with quartz and tourmaline. The ores form numerous assemblages. For many minerals more than one generation was established (Smejkal 1960).

Hydrothermal replacement type of mineralization hosted by Cretaceous carbonate rocks and hydrothermal veins within Tertiary andesites were observed in Belo Brdo (Veselinovic-Williams et al. 2007). This mineralization occurs mainly as irregularly-shaped ore bodies in limestones and siliceous rocks and is economically the most important.

Mineralization in Badoc and Crnac deposits refers to listwaenite rocks and it forms veins (Klicic 1995) whereas in Kishnica it occurs as irregular lenses, veins and impregnations at a contact between the volcanic and surrounding rocks (Dangić 1985).

Besides general geological descriptions of deposits in Trepça Mineral Belt (e.g. Veselinovic-Williams et al. 2007, Hyseni et al. 2010) some specific mineralogical investigations were conducted in the course of this study. An ore geochemistry and sulfur isotope study of Crnac deposits were done by Šoštarić et al. (2011). General $\mathrm{Zn}$ and $\mathrm{Pb}$ distribution in the Badoc deposit was described by Hyseni et al. (2010). Geothermometres based on the distribution of Cd and Mn between galena and sphalerite in Kishnica were obtained by Dangić (1985). Hydrothermal alterations of volcanic and ultramafic rocks around sulphide ores in Kishnica were studied by Dangić (1989). A detailed study of type of mineralization and its succession in samples from Hajvalija and Kishnica was made by Smejkal \& Dimitrijević (1957). 
Chemical compositions of ore minerals from Hajvalija, Badoc and Kishnica were studied by Durmishaj et al. (2006). Dickite associated with skarn mineralization and kaolinite in vein mineralisation from Crnac and Trepça deposits were described by Palinkas et al. (2009). The best known and the most economically important deposit is the Stan Terg deposit (e.g. Brammal 1930, Forgan 1950, Lieber 1975).

\section{THE STAN TERG DEPOSIT}

The Stan Terg deposit has been exploited since medieval times. It was mentioned for the first time in 1303 in the Dubrovnik Republic Chronicles (Barič 1977). Several old adits and shafts are still visible in the area. Launched at the beginning of the twentieth century, the underground mine operates up to today. There are eleven levels in the mine; the mining activities are conducted in the $9^{\text {th }}, 10^{\text {th }}$ and $11^{\text {th }}$ horizons. The Trepça ore is rich and contains 6 wt. $\%$ of $\mathrm{Pb}, 4$ wt. $\%$ of $\mathrm{Zn}, 75 \mathrm{~g} / \mathrm{t}$ of $\mathrm{Ag}$ and $102 \mathrm{~g} / \mathrm{t}$ of Bi as well as several other elements including rare ones (Féraud \& Deschamps 2009).

The Stan Terg deposit is located in the central part of Zone II in the Trepça Belt (Fig. 1). The main tectonic structure is an anticline plunging at about $40^{\circ} \mathrm{NW}$, with a prominent volcanic breccia pipe along the hinge of the asymmetric anticline. Triassic carbonates (mainly marbles) build the core of the anticline. They are surrounded by sericite schist. The breccia pipe is composed of country rocks, trachyte and quartz-latitic rocks. Skarns were formed at the interfaces between limestones or schists and the volcanic pipe (Palinkas et al. 2007, Hyseni et al. 2010).

Most of the ore bodies have the columnar shape. They are located along the carbonateschist contact and dip parallel to the plunge of the anticline and structural fabric and the dip of the flanks (Hyseni et al. 2010).

There are two main ore types in Trepça. The first one is a massive metasomatic ore. The second one is a coarse-grained type; it filled up the cavities in limestones and occurs along foliation lines in schists (Këpuska 1998). Part of the ore is controlled by paleokarstic cavities (Palinkas et al. 2007).

Four main different types of mineralization were distinguished: skarns, sulphides, sulphides-oligonite and oligonite (Këpuska \& Fejza 2000). They mention $\mathrm{Pb}$ and $\mathrm{Zn}$ as main ore elements. The minor elements are $\mathrm{Cu}, \mathrm{As}, \mathrm{Ag}, \mathrm{Bi}, \mathrm{Se}, \mathrm{Au}$ accompanied in lesser quantities by In, Ga, Ge, Cd, Ta, Ti. The minor and accompanying elements have different contents in the individual zones. Hyseni et al. (2011) surveyed the distribution of the minor and accompanying elements such as $\mathrm{Cu}, \mathrm{As}, \mathrm{Sb}, \mathrm{Bi}, \mathrm{Ni}, \mathrm{Ca}, \mathrm{Hg}, \mathrm{Ti}, \mathrm{Mn}, \mathrm{Mo}, \mathrm{Co}$ and $\mathrm{Mg}$. The analyses show that there is homogeneous content in VII-X level, while silver content shows concentration increasing depth.

\section{MINERALIZATION AT THE STAN TERG DEPOSIT}

There is extensive information on the formation of the mineralisation in the Stan Terg deposit. Schumacher (1950) distinguished two different stages of mineralization: the contact-pneumatolitic and hydrothermal stage; three stages of ore formation were described 
by Këpuska (1998): contact-metasomatic, metasomatic-hydrothermal and hydrothermal. The contact-pneumatolitic or contact-metasomatic stage is related to the skarn formations. Mainly $\mathrm{Ca}+\mathrm{Mg}+\mathrm{Fe}$ silicates such as: ilvaite, hedenbergite, garnets (andradite) and actinolite were formed together with pyrite, magnetite and first generations of sulphides. This kind of mineralization does not have economic importance, although it is scientifically interesting. Within the hydrothermal phase, three phases were described by Këpuska (1998): catathermal, meso-thermal and epithermal. At the two first stages basic sulphides (pyrite, pyrrhotite, chalcopyrite, sphalerite, arsenopyrite and galena) were formed. The most interesting is the mesothermal phase with the formation of all $\mathrm{Pb}+\mathrm{Sb}+\mathrm{Ag}+\mathrm{Cu}$-bearing minerals (tetrahedrite, bournonite, boulangerite, pyrargyrite, falkmanite) as well as $\mathrm{Au}$, native $\mathrm{Bi}$ with $\mathrm{Bi}$ sulphosalts were formed during the catathermal phase. The epithermal phase is characterized by low temperature minerals such as barite, aragonite, melnicovite, chalcedony and barite.

Galena has the major mineral of economic importance. It is mainly coarse grained. Galena is supposed to be the only silver and bismuth carrier. Up to Schumacher's (1950) publication, Ag and Bi minerals were not identified there. Schumacher (1950) supposed they may occur in the form of a isomorphic mixture of $\mathrm{Ag}_{2} \mathrm{~S}$ or $\mathrm{AgBiS}_{2}$, otherwise as tiny matildite grains. Additional investigations showed that these elements are present in other minerals as well. Tetrahedrite was described by Bermanec et al. (1987) and it contains 4.9 wt. \% of Ag. The other $\mathrm{Ag}$ and $\mathrm{Bi}$ bearer is cosalite with 0.8 wt. \% of $\mathrm{Ag}$ and 38 wt. \% of Bi (Terzić et al. 1971) as well as common boulangerite (plumosite) contains up to $0.3 \mathrm{wt} \%$ of $\mathrm{Bi}$ (Weiner 1956).

Sphalerite is the second main ore mineral; it is coarse grained, black in colour and forms crystals up to $10 \mathrm{~cm}$. Nikitin \& Duhovnik (1937) reported the following chemical composition of sphalerite: 54.4 wt. \% of $\mathrm{Zn}, 0.5$ wt. \% of Pb, 11.2 wt. \% of Fe, 32.4 wt. \% of $\mathrm{S}$ and negligible amount of As. It contains small amounts of silver. Kharbish (2007) investigated Cd contents in various sphalerite by Raman spectroscopy. The Cd content in "skarn" sphalerite reaches $2420 \pm 70 \mathrm{ppm}$ and in "hydrothermal" one $2380 \pm 420 \mathrm{ppm}$. The $\mathrm{Zn} / \mathrm{Cd}$ ratio (232 in skarn sphalerite; 230 in hydrothermal sphalerite) is similar to that described from other skarn-hydrothermal $\mathrm{Pb}+\mathrm{Zn}$ deposits (Palinkas et al. 2006). Sphalerite includes a lot of blebs of chalcopyrite and products of dissolution such as valleriite and cubanite.

Fluid inclusion studies were performed on black sphalerite by Palinkas et al. (2007), who measured $T m_{i c e}$ and $T_{h}$ in the samples from levels X, IX and V. On the base of fluid inclusion study and sulphide geothermometers, one can estimate the temperature of the sulfide formation to $360^{\circ} \mathrm{C}$ (based on arsenopyrite co-existing with pyrite and sphalerite) or between $380-405^{\circ} \mathrm{C}$ (based on the chemical composition of sphalerite in equilibrium with pyrite and pyrrhotite).

Nikitin \& Duhovnik (1937) supposed the following succession scheme: older generations of sulphide - pyrrhotite, galena, chalcopyrite, pyrite; older generation of gangue - quartz, siderite, siderite-calcite and the other generation of ore minerals - pyrite, arsenopyrite and boulangerite. The succession was closed by a younger generation of gangue: quartz, oligonite, rhodochrosite and calcite. 
In the oxidized parts of the deposits, supergene minerals can be found: covellite, cerusite, anglesite, vivianite, ludlamite, smithsonite, goethite, psilomelane, gypsum, melanterite, chalcantite (Këpuska 1998).

\section{PRELIMINARY RESULTS OF THIS SURVEY}

Our first investigations in the Trepça mineral belt reported here were performed in the Stan Terg and Artana deposits. Some pictures from our visits to Kosovo are shown in Figures 2 and 3 .

A)

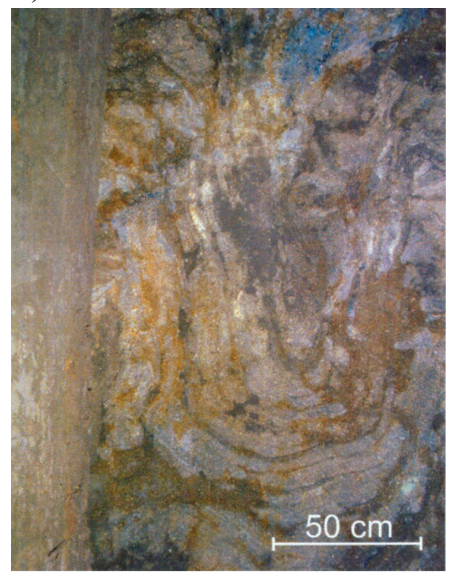

C)

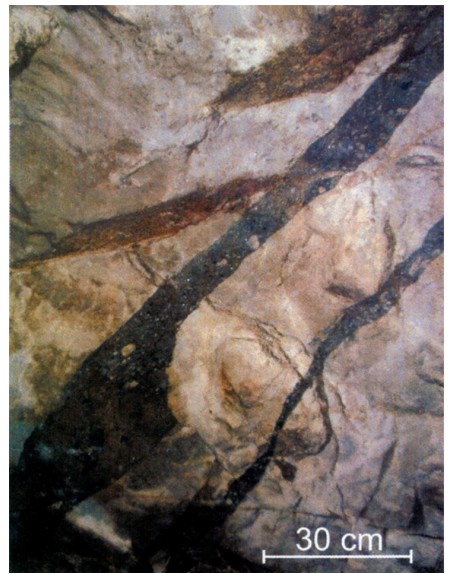

B)

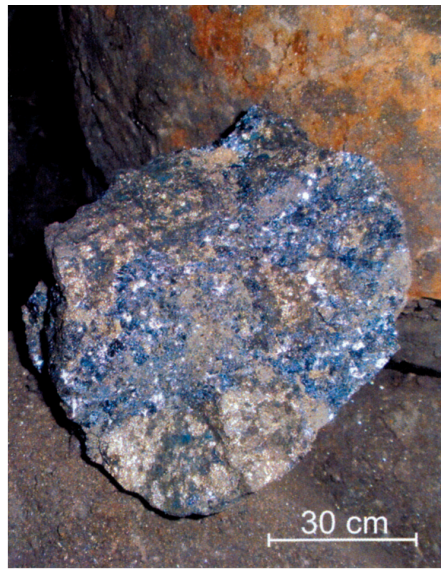

D)

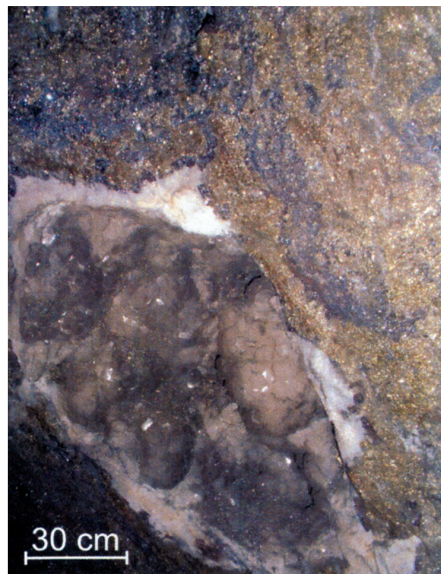

Fig. 2. Textures and position of $\mathrm{Pb}-\mathrm{Zn}$ mineralization in the underground works: $\mathrm{A}) \mathrm{Zn}-\mathrm{Pb}$ ore on the sidewall in Artana mine; B) massive $\mathrm{Zn}-\mathrm{Pb}$ ore in Artana mine; C) marbles and cracks filled with breccias grains, Stan Terg mine; D) vug filled up with huge calcite crystals in sphalerite-piryte ore on the gallery roof in Stan Terg mine 
A)

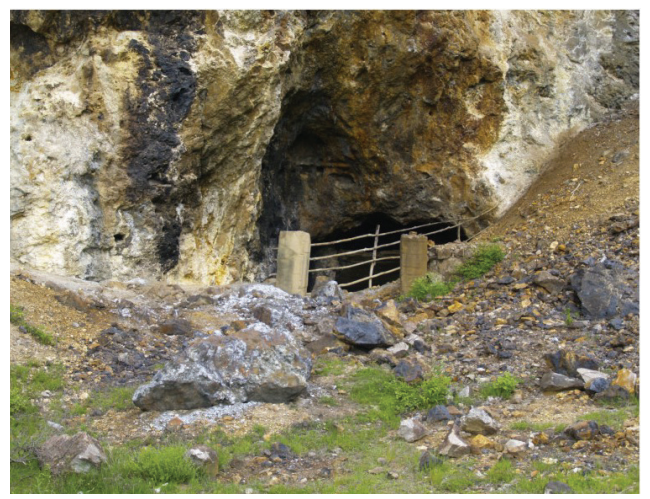

B)

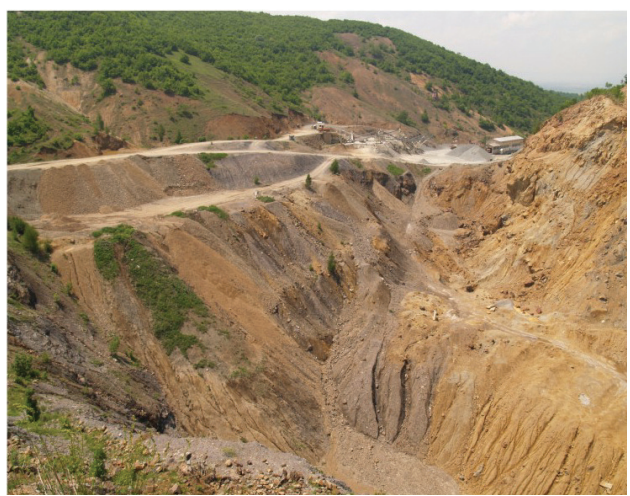

Fig. 3. Outrops of the $\mathrm{Pb}-\mathrm{Zn}$ mineralization in Kosovo: A) entrance to an old adit and primary ore blocks on the surface in Stan Terg deposit area; B) Kizhnica open pit

Two types of ores from Stan Terg: skarn and hydrothermal ore from Artana were investigated. Microscopic investigations in reflected light were performed. The chemical compositions of some minerals were confirmed with an EDS microanalyser and will be followed up by further analytical work in the near future.

The main ore minerals such as galena, sphalerite, arsenopyrite, pyrite and pyrrhotite were identified in Stan Terg. The succession scheme for mineral precipitation in all samples is very similar. Chalcopyrite usually forms small minute blebs in sphalerite or in its intergrowth with galena and sphalerite. Sometimes, tetrahedrite is associated with it and forms small grains or veinlets in chalcopyrite. This type of tetrahedrite is poor in silver, its content of silver varying from $1 \mathrm{wt}$. $\%$ to $5 \mathrm{wt}$. $\%$.

A microscopic investigation of the skarn ore (Fig. 4A, B) shows that it contains mainly pyrrhotite-magnetite mineralization. Galena is also very common. In some polished sections galena contains numerous small inclusions of native bismuth together with bismuthinite.

Hydrothermal mineralization (Fig. 4C, D) is dominated by massive sphalerite and galena. The pyrite and marcasite crystals are mostly euhedral, they were formed in the pre-ore stage. Galena is coarse-grained and sometimes contains many minute blebs or grains of rare minerals. Boulangerite together with Ag minerals (stephanite, pyrostilpnite and freibergite with $28 \%$ wt. of $\mathrm{Ag}$ ) is the most common (Fig. 4E, F). Elongated boulangerite crystals are common within the massive galena as well as in younger carbonate fillings. The youngest genetic stages of this kind of ore are represented by chalcopyrite, tetrahedrite and silver minerals. According to the present results, galena is the most economic significant mineral. In the skarn type of ore galena is a bearer of bismuth whereas in hydrothermal assemblages it is a holder of silver mineralization. 


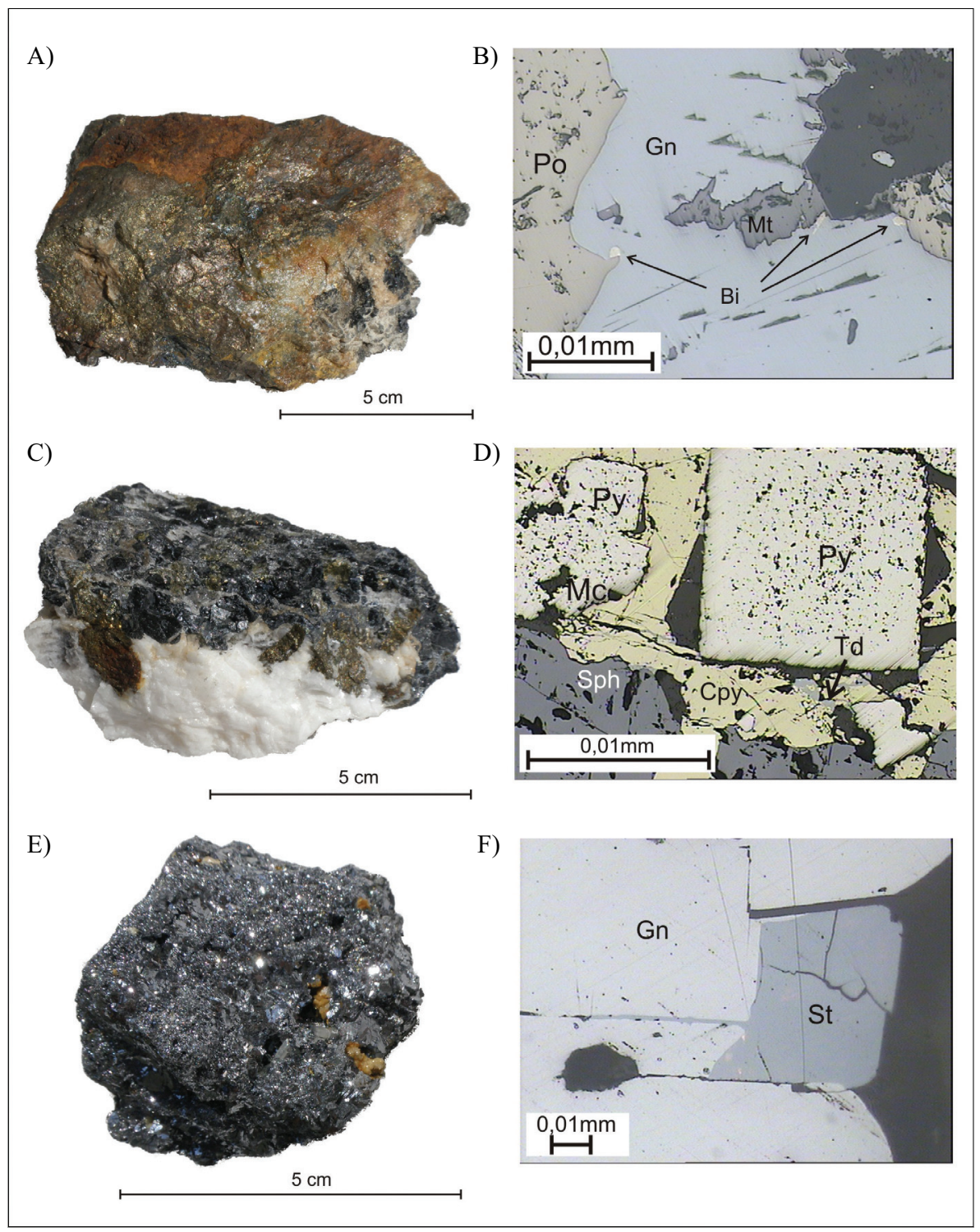

Fig 4. Macroscopic (A, C, D) and microscopic (B, D, F) photographs of studied ore from Stan Terg deposit: A) skarn ore sample; B) typical skarn mineralization: primary magnetite and pyrrhotite with younger galena with native bismuth inclusions; C) hydrothermal ore sample and its contact with marble; D) typical hydrothermal mineralization: euhedral pre-ore pyrite and marcasite grains, massive sphalerite and the youngest chalcopyrite with tetrahedrite assemblages; E) massive fine-grained galena sample; F) massive galena with stephanite grain

$\mathrm{Cpy}=$ chalcopyrite $; \mathrm{Gn}=$ galena $; \mathrm{Mt}=$ magnetite $; \mathrm{Mc}=$ marcasite $; \mathrm{Bi}=$ native bismuth; Po $=$ pyrrhotite $; \mathrm{Py}=$ pyrite $; \mathrm{Sph}=$ sphalerite, $\mathrm{St}=$ stephanite 
The observations conducted on polished sections from Artana gave results similar to those from Trepça. The samples contain mainly galena, sphalerite, pyrite, arsenopyrite, pyrrhotite and thiosulphides. Sphalerite is very rich in chalcopyrite exsolutions much more than in the Stan Terg deposit. In some samples minute grains or veinlets of stannite group minerals are seen. The gangue minerals in both deposits are quartz, various carbonates and skarn silicates in Trepça (ilvaite, hedenbergite, garnets).

\section{CONCLUSIONS}

The ore mineralogy of the Stan Terg deposit is characterized mainly by main sulphides as pyrite, pyrrhotite, sphalerite, galena, boulangerite as well as numerous carbonate minerals - dolomite, calcite, kutnahorite, siderite and rhodochrosite and their intermediate members. In less amounts quartz and skarn sillicates (hedenbergite, ilvaite) occurs. Resent research allow us to identify numerous rare minerals - bournonite, heteromorphite members of the stannite group, members of the tetrahedrite group as well as several silver bearing minerals stephanite, pyrargyrite, polybasite and freieslebenite. The mineralogy of other studied deposits - Kishnica and Artana is similar, but only main sulphide minerals usually occur.

In the near future we plan to pursue research also at the Kishnica, Hajvalija and other smaller deposits. The investigations will comprise the basic mineralogical research - identification of the ore minerals, their relationships (structures and textures), paragenesis, mineralization stages as well as chemical composition of the main and accessory minerals. The main attention will be paid to the main ore minerals and to the contents and bearers of the minor or accessory (critical) elements such as Ge, In, Ga, Au, Bi, Te, Se, Sn and Ag. We would like to identify the main bearers of those elements, which could be very important for the methods of extraction. After basic mineralogical research, we plan to do fluid inclusion and stable isotope study to determine the ore forming conditions. We hope that our research will help to improve the technological processes in the Trepça mining company as well as it will give significant information on the origin of the $\mathrm{Pb}+\mathrm{Zn}$ hydrothermal mineralization in Trepça Mineral Belt. We are strengthening our cooperation with Trepça and we have established a triangular cooperation between Zakład Górniczy Bolesław in Bukowno, us and Trepça, as discussed during the Trepça management visit in Cracow in May 2012.

The authors thank all the staff as well as the geologists of the Artana and Stan Terg mines for hosting multiple visits in the mines related to our collecting the samples. They explained the history and techniques of mining in each of them and expressed interest in our suggestions on particular mineralogical ore researches. The authors wish to thank Jean Féraud for indicating to us certain literature and for a valuable review of this manuscript. 


\section{REFERENCES}

Barič L., 1977. Die 70 Mineralien vom “Alten Markt”. Die Blei-Zinkerz-Lagerstätte von Trepča in Südjugoslawien und ihre Mineralien. Lapis, 2.11, 10-15.

Bermanec V., Tibljaš D. \& Zebec V., 1987. Tetraedrit z rudnika Stari Trg. Geološki Vjesnik, 40, 89-95.

Brammal A., 1930. The Stantrg lead-zinc mine, Yougoslavia. The Mining Magazine, 42, 9-15.

Dangić A., 1985. Minor element distribution between galena and sphalerite as a geothermometer-application to two lead-zinc areas in Yugoslavia. Economic Geology, 80, 180-183.

Dangić A., 1989. Alteration phyllosicates - wall rock alternation of intermediate vocanics and utramafic rocks around $\mathrm{Pb}-\mathrm{Zn}$ sulphide ores. Annales Geologiques de la Peninsule Balkanique, III, 420-444.

Durmishaj B., Tashko A., Sinojmeri A. \& Neziraj A., 2009. Mbi përbeërjen kimike të fazave minerale të vendburimeve Hajvali, Badovc dhe Kizhnicë (Kosovë). Buletini i Shkencave Gjeologjike, 2, 91-100.

Féraud J. \& Deschamps Y., 2009. French scientific cooperation 2007-2008 on the Trepča leadzinc-silver mine and the gold potential of Novo Brdo/Artana tailings (Kosovo). Final Report, BRGM/RP-57204-FR.

Forgan C.B., 1950. Ore deposits at the Stan Terglead-zinc mine, Yougoslavia. International Geological Congress, Report of the eighteenth session Great Britain 1948, Part VII, The Geology, paragenesis, and reserves of the ores of lead and zinc, 290-307.

Hyseni S., Durmishaj B., Fetahaj B. \& Large D., 2010. Trepça ore belt and lead and zinc distribution in Badove mineral deposit, Kosovo (SE Europe). ARPN Journal of Engineering and Applied Sciences, 5, 8, 1-9.

Hyseni S., Durmishaj B., Rama M. \& Muharrem Z., 2010. Trepça ore belt and Beloberdo mineral deposit-geological overview and interpretation, Kosovo. Journal of International Environmental Application and Science, 5, 2, 258-263.

Hyseni S., Durmishaj B., Fetahaj B., Shala F., Berisha A. \& Large D., 2010. Trepça ore belt and Stan Terg mine - Geological overview and interpretation, Kosovo (SE Europe). Geologija, 53/1, 87-92.

Hyseni S., Durmishaj B., Berisha A. \& Operta M, 2011. Accompanying elements and their distribution by levels VII-X in the mineral deposit Stan Terg - "Trepça". Journal of Basic and Applied Scientific Research, 1(8), 832-836.

Jankovic S., 1995. The principal metallogenic features of the Kopaonik District. Geology and Metallogeny of the Kopaonik Mt. Symposium, 79-101.

Këpuska H., 1998. Distribumi i elementeve shpërndarëse dhe mikroelementeve përcjellëse ne mineralet kryesore xeheroformonjëse në vendburimi e plumb-zunkut "Trepça". Universiteti i Prishinës, Fakulteti Xehetarisë-Metalurgjisë [doctoral dissertation].

Këpuska H. \& Fejza I., 2000. Zonaliteti ne vendburimin e plumb-zunkut “Trepça”. Buletini i Shkencave Gjeologjike, 17(36), 53-56. 
Kharbish S., 2007. A Raman spectroscopic investigation of Fe-rich sphalerite: effect of fesubstitution. Physics and Chemistry of Minerals, 34, 551-558.

Klicic M., 1995. Deposits of lead and zinc in the ore field "Ajvalija-Kisnica". Geology and Metallogeny of the Kopaonik Mt. Symposium, 305-313.

Lieber W., 1975. Trepça und seine Mineralien. Der Aufschuss, 6, 225-235.

Miletic G., 1997. Structural control volcanic apparatus of continuous lead and zinc mineralization of the Kopaonik metallogenic district. Symposium in Serbian IRL, Belgrade, 91-99.

Palinkas S., Palinkas L. \& Molnar F., 2006. Trace-elements content of sphalerite and associated minerals in Stari Trg Pb-Zn deposit, Trepça, Kosovo, Goldschmidt Conference Abstracts.

Palinkas S., Palinkas L.A., Spangenberg J., Luders V. \& Molnar F., 2007. Geochemistry of sulphides form Pb-Zn-Ag hydrothermal-metasomatic deposit Stari Trg, Trepca, Kosovo. William R. Dickinson's Symposium on Ores and Orogenesis 2007. Circum-Pacific Tectonics, Geologic Evolution and Ore Deposits, Tucson, Arizona, 24-30 September 2007, Abstract 275, Poster session 27.

Palinkas S., Sostarić S., Bermanec V., Palinkas L., Prochaska W., Furić K. \& Smajlović J., 2009. Dickite and kaolinite in the Pb-Zn-Ag sulphide deposits of northern Kosovo (Trepça and Crnac). Clay Minerals, 44, 1, 67-79.

Nikitin V. \& Duhovnik J., 1937. Cinkovo-svinčeni rudnik "Stari trg" v okolici Trepce. $R u$ darski Zbornik 1936-1937, Številka 3, 194-225.

Schumacher F., 1950. Die Lagerstätte der Trepça und ihre Umgebung. Izdvacko preduzece Saveta za energetiku i ekstraktivnu industriju vlade fnrj, Belgrad.

Schumacher F., 1952. Die Kristalldrusen der Blei-Zink-Lagerstätte "Trepca”, Jugoslawien. Der Aufschuss, 3, 5-9, 24-26.

Smejkal S., 1960. Strukture, mineralizacije, mineralne parageneze i geneza olovo cinkovih lezišta kopaonicke oblasti. Rudarsko geološki fakultet Univerziteta u Beogradu, Beograd [doctoral dissertation].

Smejkal S. \& Dimitrijević M., 1957. Olovno-cinkano leziste Ajvalije, II Kongres Geologa Jugoslavije, 8014 IX 1957, Sarajevo.

Šoštarić S., Palinkaš L., Topa D., Spangenberg J. \& Prochaska W., 2011. Silver-based metal epithermal vein and listwaenite types of deposit Crnac, Rogozna Mts., Kosovo. Part I: Ore mineral geochemistry and sulfur isotope study. Ore Geology Reviews, 40, 65-80.

Terzić S., Sommerauer J. \& Harnik A., 1971. Macroscopic cosalite crystals from the Pb-Zn ore deposit Trepča (Yugoslavia). Schweizerische Mineralogische und Petrographische Mitteilungen, 54, 1, 209-211.

Veselinovic-Williams M., Treloar P. \& Rankin A., 2007. The origin and evolution of the Belo Brdo $\mathrm{Pb}-\mathrm{Zn}$ deposit, northern Kosovo: a preliminary field based interpretation. Proceedings of the Ninth Biennial SGA Meeting, Dublin, 161-164.

Weiner K., 1956. Über Plumosit von der Trepća und von Grube Georg (Siergerland). Fortschritte der Mineralogie Deutsche Mineralogische Gesellschaft, 34/1, 27-28. 
